\title{
Using MODIS derived $f$ PAR with ground based flux tower measurements to derive the light use efficiency for two Canadian peatlands
}

\author{
J. Connolly ${ }^{1}$, N. T. Roulet ${ }^{2}$, J. W. Seaquist ${ }^{3}$, N. M. Holden ${ }^{1}$, P. M. Lafleur ${ }^{4}$, E. R. Humphreys ${ }^{5}$, B. W. Heumann ${ }^{6}$, and \\ S. M. Ward ${ }^{1}$ \\ ${ }^{1}$ Biosystems Engineering, UCD School of Agriculture, Food Science and Veterinary Medicine, University College Dublin, \\ Dublin, Ireland \\ ${ }^{2}$ Department of Geography and Global Environmental and Climate Change Centre (GEC3), McGill University, Montreal, \\ Quebec, Canada \\ ${ }^{3}$ Department of Physical Geography and Ecosystems Analysis, Sölvegatan 12, 22362 Lund, Sweden \\ ${ }^{4}$ Department of Geography, Trent University, Peterborough, Ontario, Canada \\ ${ }^{5}$ Department of Geography, Carleton University, Ottawa, Ontario, Canada \\ ${ }^{6}$ Department of Geography, Carolina Population Center, University of North Carolina at Chapel Hill, USA
}

Received: 1 February 2008 - Published in Biogeosciences Discuss.: 18 April 2008

Revised: 2 February 2009 - Accepted: 2 February 2009 - Published: 19 February 2009

\begin{abstract}
We used satellite remote sensing data; fraction of photosynthetically active radiation absorbed by vegetation ( $f$ PAR) from the Moderate Resolution Imaging Spectroradiometer (MODIS) in combination with tower eddy covariance and meteorological measurements to characterise the Light Use Efficiency parameter $(\varepsilon)$ variability and the maxi$\operatorname{mum} \varepsilon\left(\varepsilon_{\max }\right)$ for two contrasting Canadian peatlands. Eightday MODIS $f$ PAR data were acquired for the Mer Bleue (2000 to 2003) and Western Peatland (2004). Flux tower eddy covariance and meteorological measurements were integrated to the same eight-day time stamps as the MODIS $f$ PAR data. A light use efficiency model: GPP $=\varepsilon \times$ APAR (where GPP is Gross Primary Productivity and APAR is absorbed photosynthetically active radiation) was used to calculate $\varepsilon$. The $\varepsilon_{\max }$ value for each year (2000 to 2003) at the Mer Bleue bog ranged from $0.58 \mathrm{~g} \mathrm{C} \mathrm{MJ}^{-1}$ to $0.78 \mathrm{~g} \mathrm{C} \mathrm{MJ}^{-1}$ and was $0.91 \mathrm{~g} \mathrm{C} \mathrm{MJ}^{-1}$ in 2004, for the Western Peatland. The average growing season $\varepsilon$ for the Mer Bleue bog for the four year period was $0.35 \mathrm{~g} \mathrm{C} \mathrm{MJ}^{-1}$ and for the Western Peatland in 2004 was $0.57 \mathrm{~g} \mathrm{C} \mathrm{MJ}^{-1}$. The average snow free period for the Mer Bleue bog over the four years was
\end{abstract}

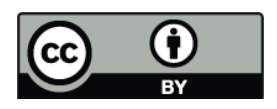

Correspondence to: J. Connolly (john.connolly0@ucd.ie)
$0.27 \mathrm{~g} \mathrm{C} \mathrm{MJ}^{-1}$ and for the Western Peatland in 2004 was $0.39 \mathrm{~g} \mathrm{C} \mathrm{MJ}^{-1}$. Using the light use efficiency method we calculated the $\varepsilon_{\max }$ and the annual variability in $\varepsilon$ for two Canadian peatlands. We determined that temperature was a growth-limiting factor at both sites Vapour Pressure Deficit (VPD) however was not. MODIS $f$ PAR is a useful tool for the characterization of $\varepsilon$ at flux tower sites.

\section{Introduction}

Northern peatlands contain approximately one third of global soil carbon (Gorham, 1991). They have been accumulating carbon for the last 6000 to 10000 years of the Holocene (Vitt et al., 2000; Gorham et al., 2003). Few multi-year flux measurement programs have been conducted on peatland ecosystems (e.g. Lafleur et al., 2001; Arneth et al., 2002; Aurela et al., 2002; Lafleur et al., 2003), but available data suggest that carbon accumulation continues to occur. Peatlands accumulate carbon because net primary productivity (NPP), on average, exceeds decomposition. NPP in peatlands is not particularly large, but decomposition rates are low because the high water content reduces oxygen diffusion into litter and surface horizons and the litter of the plant types that grow on

Published by Copernicus Publications on behalf of the European Geosciences Union. 
many peatlands, particularly bogs, is not readily decomposed (Malmer and Wallén, 2004).

Climate simulations have indicated that higher latitudes will probably experience warming and changes in available moisture (precipitation-evapotranspiration) (Albritton and Meira Filho, 2001). This has raised concern over whether the environmental conditions conducive to peatland carbon accumulation will be sustained in the future (e.g. Moore et al., 1998). Many of these peatland types are located in remote areas of the boreal and subarctic climatic zones therefore tools that utilise remotely sensed data to infer changes in ecosystem productivity and net carbon exchange would be very useful. Remote sensing can be used to estimate NPP over large areas (Running et al., 1999; Ahl et al., 2004). While there has been considerable effort to develop these types of tools for forested and cropland ecosystems (e.g. Potter et al., 1993, Turner et al., 2002, 2003; Ahl et al., 2004) peatlands have received little attention.

Monteith (1972) first proposed an approach to relate $f$ PAR to biomass production that became known as the light use efficiency (LUE) model (Hunt, 1994; Gower et al., 1999; Brogaard et al., 2005). The LUE model of gross primary production (GPP in $\mathrm{g} \mathrm{C} \mathrm{m}^{-2} \mathrm{~d}^{-1}$ ) is generally given as:

$\mathrm{GPP}=\varepsilon \times \mathrm{APAR}$

where $\varepsilon$ is the light use efficiency parameter $\left(\mathrm{g} \mathrm{C} \mathrm{MJ}^{-1}\right)$ and APAR is $M J m^{-2} \mathrm{~d}^{-1}$. APAR is generally given as:

$\mathrm{APAR}=\downarrow \mathrm{PAR} \times f \mathrm{PAR}$

where $\downarrow$ PAR is incident photosynthetically active radiation and $f$ PAR is a fraction of photosynthetically active radiation that is absorbed.

$f$ PAR is a key biological property that is important for estimating canopy photosynthesis (Goetz et al., 1999; Seaquist et al., 2003) because it characterizes vegetation canopy function and energy absorption capacity (Myneni et al., 2002, 2003; Wang et al., 2001). It is a measure of the proportion of available radiation in the photosynthetically active wavelengths $(0.4$ to $0.7 \mu \mathrm{m}$ ) that a canopy absorbs (Savtchenko et al., 2003; Myneni et al., 2003; Fensholt et al., 2004). f PAR is also the radiometric equivalent of leaf area index (Running et al., 2000).

Early studies assumed that LUE or $\varepsilon$ was constant. Monteith's (1972) original theory was designed for well-watered crops only during the growing season (Heinsch et al., 2003). The LUE is based on the positive linear relationship between NPP and absorbed photosynthetically active radiation (APAR). It is used to translate remotely sensed estimates of light absorption into GPP or NPP (Ruimy et al., 1994; Lobell et al., 2002). However $\varepsilon$ has been shown to vary spatially between biomes, ecosystems, and plant species, and temporally over the growing season even within spatially homogeneous vegetation canopies (Ruimy et al., 1994; Turner et al., 2002; Brogaard et al., 2005). Photosynthesis and respiration are strongly sensitive to environmental controls such as VPD and air temperatures (Fan et al., 1995; Kimball et al., 2000). Heinsch et al. (2003), extrapolated the LUE theory to perennial plants living throughout the year and thus were subject to stresses such as temperature and VPD. Low temperatures affect plants abilities to photosynthesize and a high VPD has been shown to inhibit photosynthesis by causing stomata closure (Heinsch et al., 2003). Nutrient conditions can also affect photosynthesis. Ombrotrophic peatlands experience poor nutrient condition however, the vegetation that grows in peatlands is adapted to these poor nutrient conditions and therefore the nutrient effect should be manifested through reflectance. Estimates of GPP from LUE models may be improved if vegetation association or ecosystem level specific parameter values are used (Goetz and Prince, 1999; Ahl et al., 2004; Coursolle et al., 2006). Several authors have suggested that more work is needed to characterise the spatial and temporal variability in $\varepsilon$ (Ruimy et al., 1994; Goetz and Prince, 1998; Gower et al., 1999). This study uses the light use efficiency model approach to estimate a value for $\varepsilon$ that has been attenuated by the sub-optimal environmental conditions of temperature and vapour pressure deficit. Therefore the objectives of this work were a) to examine how $\varepsilon$ varied throughout the growing season and $b$ ) to derive a maximum annual estimated $\varepsilon\left(\varepsilon_{\max }\right)$ for two contrasting Canadian peatlands using MODIS derived $f$ PAR.

\section{Methods}

\subsection{Peatland study sites}

Two Fluxnet Canada Research Network sites were used in this study, the Eastern (Mer Bleue bog) and Western Peatland sites, both equipped with eddy covariance flux measurement towers. The Mer Bleue bog is located in the Ottawa valleySt. Lawrence Lowland, Ontario $\left(45^{\circ} 24^{\prime} \mathrm{N}\right.$ latitude, $75^{\circ} 30^{\prime} \mathrm{W}$ longitude) (Lafleur et al., 2001). The elevation of the bog is $70 \mathrm{~m}$ (Smith and Lafleur, 2003). It is a raised, low-shrub, ombrotrophic bog of 2800 ha (Moore et al., 2002; Bubier et al., 2003). Peat depths range from 5 to $6 \mathrm{~m}$ near the tower site to $\sim 2 \mathrm{~m}$ at the edges of the bog (Bubier et al., 2003; Lafleur et al., 2003). This bog is representative of raised shrub bogs of the boreal region (Lafleur et al., 2001). The climate of the region is cool continental, with a mean annual temperature of $5.8^{\circ} \mathrm{C}$ and an annual precipitation of $910 \mathrm{~mm}$ (Lafleur et al., 2003). The coldest month is January $\left(-10.8^{\circ} \mathrm{C}\right)$ and the warmest July $\left(20.8^{\circ} \mathrm{C}\right)$. Over three quarters of the annual precipitation falls as rain and the average growing season (May to September) precipitation is $410 \mathrm{~mm}$ (Lafleur et al., 2003). The plant communities on the bog are dominated by ericaceous shrubs and Sphagnum mosses with secondary communities consisting of deciduous shrubs, sedges and trees $(\mathrm{Bu}-$ bier et al., 2003). The water table during the growing season 
over the five years was between 20 and $73 \mathrm{~cm}$ below the surface at the Mer Bleue.

The Western Peatland site is located in the La Biche River area in Alberta ( $54^{\circ} 57^{\prime} \mathrm{N}$ latitude, $112^{\circ} 28^{\prime} \mathrm{W}$ longitude). The site is a moderately rich treed fen (Syed et al., 2006). The climate of the region is continental, with a mean annual temperature of $2.1^{\circ} \mathrm{C}$ and the annual precipitation is $504 \mathrm{~mm}$ (Syed et al., 2006). The coldest month is January $\left(-15^{\circ} \mathrm{C}\right)$ and the warmest is July $\left(\sim 16^{\circ} \mathrm{C}\right)$. The vegetation of the study site was dominated by stunted trees of Picea mariana and Larix laricina, with high abundance of a shrub, Betula pumila, and a wide range of moss species (Syed et al., 2006).

\subsection{In situ measurements}

The eddy covariance towers collect data that permit daily records of net ecosystem exchange (NEE), ecosystem respiration (ER) and $\downarrow$ PAR to be made (Lafleur at al., 2001; Moore et al., 2002, Lafleur et al., 2003 and Syed et al., 2006). Measurements began at Mer Bleue in 1998 and in 2003 at the Western Peatland (Lafleur et al., 2003; Syed et al., 2006). $\downarrow$ PAR was measured at both sites using quantum sensors (Lafleur et al., 2001; Lafleur et al., 2003; Syed et al., 2006). NEE and ER were measured at the Mer Bleue bog with a closed-path infrared gas analyzer (initially a LI6262 but upgraded in 2002 to a LI7000, LI-COR, Lincoln, NB, USA) (Lafleur et al., 2001, 2003) and at the Western Peatland with a fast response closed-path infra-red gas analyzer (LI7000, LI-COR, Lincoln, NB, USA) (Syed et al., 2006). Night time NEE is taken to be a direct measurement of ER (Lafleur et al., 2003), and extrapolated to daytime conditions using ER vs. temperature functions. At both sites, several environmental measurements were also made in support of the flux tower data including: air temperature, relative humidity, wind speed, soil temperature and depth to water table from the peat surface. Measurements of precipitation, snow depth and atmospheric pressure were also taken at the Western Peatland. Details of the environmental measurements can be found in Lafleur et al. (2001, 2003), Syed et al. (2006). Tower data were assessed for quality assurance and gap-filling techniques were employed, as described by Lafleur et al. (2005) for Mer Bleue and Syed et al. (2006) for the Western Peatland.

Gross primary production (GPP) is the total amount of carbon that is fixed by plants. Approximations of GPP also called GEP (Chapin et al., 2006, Moore et al., 2006) were derived from micrometeorological eddy covariance measurements of gross ecosystem productivity (GEP) i.e., NEE minus ER (Law et al., 2000). NEE is the carbon dioxide exchange of terrestrial ecosystems that is driven by the balance between the sequestration of $\mathrm{CO}_{2}$ by photosynthesis and its emission by soil and plants i.e. ecosystem respiration (Bubier et al., 2003). GPP was estimated as:

$\mathrm{GPP}=\mathrm{NEE}-\mathrm{ER}$
Where GPP $=$ gross primary productivity $\left(\mathrm{g} \mathrm{C} \mathrm{m}^{-2} \mathrm{~d}^{-1}\right)$, $\mathrm{NEE}=$ net ecosystem exchange $\left(\mathrm{g} \mathrm{C} \mathrm{m}^{-2} \mathrm{~d}^{-1}\right), \mathrm{ER}=$ ecosystem respiration $\left(\mathrm{g} \mathrm{C} \mathrm{m}^{-2} \mathrm{~d}^{-1}\right)$. The flux measurements were collated on a half hourly time step and used to calculate a mean daily value for 8-day time period's consistent with the 8-day composite $f$ PAR data from MODIS on the Terra (EOS AM) satellite (Yang et al., 2006). The methodology used in this study required that the field-measured data be compatible with the 8-day period time step of the MODIS $f$ PAR data, therefore there is a loss of the day-to-day variation (Sims et al., 2005).

\subsection{Satellite images}

Terra (EOS AM) was launched in 1999 (Salomonson, 2002) and began producing the Moderate Resolution Imaging Spectroradiometer (MODIS) data, including MOD15A2 ( $f$ PAR) data, in 2000 (Myneni et al., 2002). MODIS has thirty-six spectral bands including middle and long-wave infrared (Savtchenko et al., 2003; Justice et al., 1998). MODIS collection 4 data were used in this study, these data were downloaded from the Land Processes Distributed Active Archive Center at http://edcimswww.cr.usgs.gov/pub/ imswelcome/. In the $f$ PAR datasets for the Mer Bleue, errors were recorded in mid summer from 2000 to 2003. The code generating these data was found to contain a bug however this does not invalidate the concept of the analysis. The MODIS quality control (QC) attributes these errors to unclassified problems other than geometry (Myneni et al., 2003). These problems led to high $f$ PAR values ranging from between 1.0 and 2.5, The MODIS system also malfunctioned in 2001 from Julian day 177 to 193 (Wan et al., 2004; http://daac.gsfc.nasa.gov/MODIS/Terra/ MODIS_Terra_outages.shtml, 2005) resulting in a complete loss of data for this period. On four occasions during 2003 and $2004 f$ PAR values were unusually low. A data outage accounts for one occasion in August 2004 (Kempler, 2005). MODIS QC attributed the other three errors to data not produced at all (non-terrestrial biome) or the data were classified as sub-standard and to be used with caution (Myneni et al., 2003). Erroroneous data were excluded from the calculations. The $f$ PAR values are composited over an 8 -day period and the value used is the highest $f$ PAR value in that 8 -day period (Yang et al., 2006).

Each MODIS $f$ PAR image has a pixel resolution of $1 \mathrm{~km}^{2}$. The footprint of an EC tower is $\sim 1 \mathrm{~km}^{2}$ (Running et al., 2004) however $80 \%$ of the flux comes from within $200 \mathrm{~m}$ of the tower site (Lafleur personal communication, 2006). Therefore, the measurements from the EC tower (NEE, ER and $\downarrow$ PAR) and $f$ PAR from MODIS were obtained from the same peatland area at each study site and could be used to calculate $\varepsilon$. Both the Mer Bleue bog and the Western Peatland sites were classified as mixed forests in the IGBP MODIS biome classification scheme (Lotsch et al., 2003). However, to test the reliability of MODIS-derived $f$ PAR 


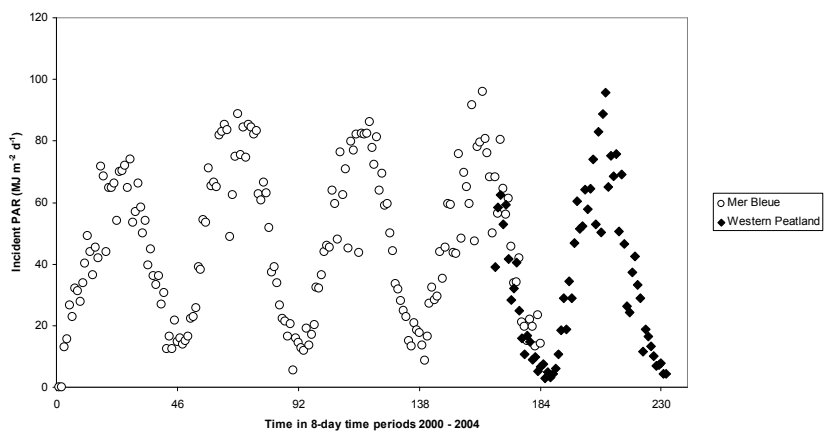

Fig. 1. Average daily $\downarrow$ PAR for an 8-day time period for the Mer Bleue bog, Ontario, Ontario, (2000-2003) and for the Western Peatland, Alberta, (end 2003-2004).

values we used a simple Beers Law approach (Ahl et al., 2005, Turner et al., 2005).

$f \mathrm{PAR}=1-\exp (\mathrm{LAI}(-k))$

Where LAI is field measured data from Mer Bleue (Moore et al., 2002 and Sonnentag et al., 2007) and $\mathrm{k}$ is an extinction coefficient of 0.5. The algorithm associated with MODIS $f$ PAR uses a simple selection rule whereby the maximum $f$ PAR value over the 8-day period is chosen to be the representative value for the output pixel (Heinsch et al., 2003). The first day of the first compositing period is the 1st January and the first day of the second compositing period is 9th January. The 8-day time step of the MODIS $f$ PAR product was used as a template to calculate e. Throughout one calendar year there are forty-five full 8-day compositing periods and one 5-day compositing period at the end of the year.

Over 200 MODIS $f$ PAR images were acquired for the Mer Bleue bog site (representing four years of data) and 65 for the Western Peatland site (representing one and a half years of data). In order to extract the $f$ PAR data it was necessary to pre-process the images within Erdas Imagine. The pre-processing included reprojecting the $f$ PAR images from the MODIS sinusoidal projection to Universal Transverse Mercator (UTM) zone 18 for the Mer Bleue bog and UTM zone 12 for the Western peatland with the World Geodetic System (WGS) $84 \mathrm{~N}$ datum using ERDAS IMAGINE software (v. 8.5, ERDAS, Inc.) to enable extraction of $f$ PAR values for each tower site (Lopes, 2003, Heumann, personal communication, 2005). The data were imported to IdrisiTM and subset to an area around each observation tower. A 1$\mathrm{km}^{2}$ mask was created over the tower area and $f$ PAR data were extracted for each tower pixel for all images over the time period.

\subsection{Variability in $\varepsilon$}

The variability in $\varepsilon$ is due to maintenance respiration costs and sub optimal weather conditions (Heinsch et al., 2003). The mean minimum daily temperature (Tmin) and VPD were acquired from both the Mer Bleue bog and the Western Peatland datasets and plotted separately against $\varepsilon$ to determine the effects of each on the $\varepsilon$. Saturated VPD was calculated using the following formula (Snyder and Paw U, 2006)

$e_{s}=\left(\frac{17.27 T}{T+237.3}\right)$

Where $e_{s}$ is saturated VPD $(\mathrm{kPa})$ and $T=$ temperature $\left({ }^{\circ} \mathrm{C}\right)$.

The VPD was then calculated from $e_{s}$ using relative humidity data from both datasets in the following equation:

$\mathrm{VPD}=\left(e_{s}-\left(\left(\frac{\mathrm{RH}}{100}\right) \times e_{s}\right)\right) \times 1000$

Where RH is relative humidity.

\section{Results and discussion}

All results are presented as mean daily values for each 8day time step. Data for $\downarrow$ PAR, $f$ PAR and GPP are shown because they are the main constituents for deriving $\varepsilon$ and can be used to explain the structure of the derived $\varepsilon$ dataset.

\subsection{Daily $\downarrow$ PAR}

The plots of $\downarrow$ PAR against time (Fig. 1) show strong association with Sun-Earth geometry. The maximum average daily $\downarrow$ PAR for both the Mer Bleue bog and the Western Peatland ranges between 10 to $12 \mathrm{MJ} \mathrm{m}^{-2} \mathrm{~d}^{-1}$. These values are slightly lower than those reported by Turner et al. (2003), but both peatland sites reported here are located farther north. The data are averaged out over 8-day periods, which means that the day-to-day variation in $\downarrow$ PAR is not seen. Peak $\downarrow$ PAR in 2000 was lower than the following years, perhaps because 2000 was a wetter year (Bubier et al., 2003), and therefore cloudier thus leading to a reduction in $\downarrow$ PAR.

\subsection{MODIS $f$ PAR}

The spatial resolution of both the tower and the MODIS $f$ PAR pixel is $1 \mathrm{~km}$. The flux tower is located $200 \mathrm{~m}$ from the western edge of the MODIS $f$ PAR pixel. However, since $80 \%$ of the flux comes from within $200 \mathrm{~m}$ of the tower, the spatial resolution of the tower and the MODIS pixel were deemed to be compatible. There is considerable variation in MODIS $f$ PAR over each growing season (Fig. 2), however the maximum values for each year are quite similar at about 0.95 . The uncertainty of whether or not the IGBP biome misclassification had an effect on MODIS $f$ PAR for the Mer Bleue was explored using $f$ PAR derived from late summer field measured LAI using a simple Beers Law approach (Eq. 4).

Both Moore et al. (2002) and Sonnentag et al. (2007) report that typical mid-August LAI values for bog and poorfen vegetation at the Mer Bleue bog site range from 1.30 to 


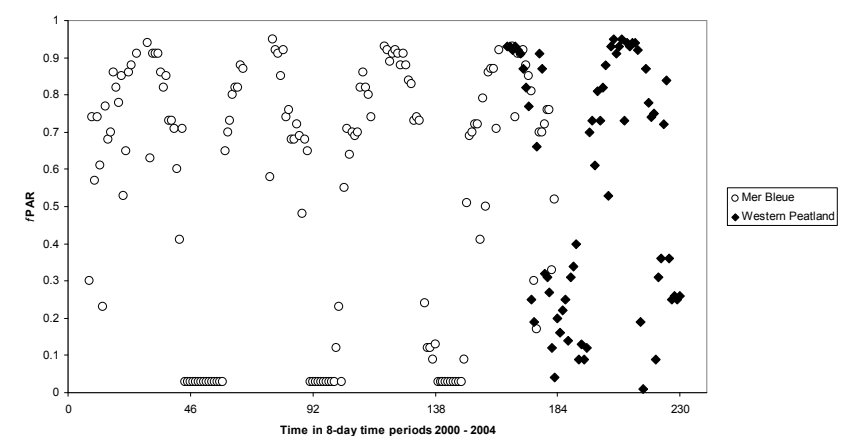

Fig. 2. MODIS fPAR data for Mer Bleue bog, Ontario (2000 to 2003) and for Western Peatland, Alberta (2003-2004) (46 and a bit 8-day time periods in a year).

2.13. Based on these values, the estimated canopy $f$ PAR (derived using Beer's Law with an extinction coefficient of $0.5,1-\exp (1.3(-0.5))=0.48$ and $1-\exp (2.13(-0.5))=0.66)$ would range from 0.48 to 0.66 (Frolking et al., 2002). Assuming moss absorbs $85 \%$ of the remaining $\downarrow$ PAR (Frolking et al., 2002) total canopy $f$ PAR would then range from 0.92 to 0.95 . The MODIS $f$ PAR data were consistent with the LAI derived $f$ PAR data from the field measurements. This indicates that despite the IGBP misclassification for the Mer Bleue, that there is little difference in the MODIS $f$ PAR values.

The $f$ PAR values are strongly associated with sun-earth geometry, but there is also a strong relationship with snow cover. The increase in $f$ PAR at Mer Bleue coincides with the snow melt period in 2001 and 2002 however in 2000 and 2003 when $f$ PAR increases there was still around $20 \mathrm{~cm}$ of snow on the ground (Roulet et al., 2007). Towards the end of each year there is a downturn in $f$ PAR over several compositing periods, probably due to the presence of snow on the bog. The $f$ PAR results for the Western Peatland have similar maximum summer values as the Mer Bleue bog at $\sim 0.95$.

However the winter values for 2002 and 2003 are very different as there are few very low $f$ PAR. Since GPP is very low during this time there is no impact on the $\varepsilon$ calculation. The $f$ PAR values at the Western Peatland do depict the same trend as those at the Mer Bleue. They do not go to zero during the winter probably because it is a treed fen. The trees will always absorb some $\downarrow$ PAR and thus rarely go to zero, this is assuming winter starts on Julian day 335 and ends on Julian day 59 then the range of winter $f$ PAR values is from 0.09 to 0.40 .

There was uncertainty surrounding a number of data points in Fig. 2, as they did not conform to expected patterns. Turner et al. (2005) found $f$ PAR to be stable in summer time and therefore large, short-term differences suggest problems with the source data. In early 2001, $f$ PAR was reduced to zero for two consecutive 8-day periods. The MODIS QC data were examined and this issue was identified as occur-

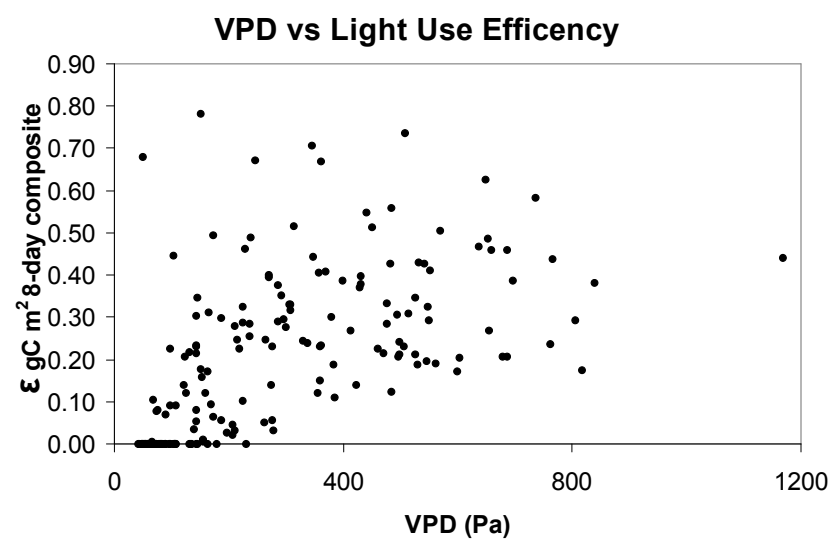

Fig. 3. The relationship between Light Use Efficiency and VPD at the Mer Bleue.

ring due to a malfunction in the MODIS sensor (Wan et al., 2004). During the growing season there are occasions when $f$ PAR is low resulting in high $\varepsilon$ values. The $f$ PAR values may be low for a number of reasons such as cloud contamination (Running et al., 2004) and sensor problems (Myneni et al., 2003). At the Western Peatland low $f$ PAR values were present for two consecutive 8-day compositing periods during September 2004. The $f$ PAR values for these two periods were 0.19 and 0.01. MODIS QC attributed these low values to failure of the main (RT) method (Myneni et al., 2003). Normally $f$ PAR values should fall between 0 and 1 , however on a number of occasions $f$ PAR values were greater than 1 . The reason for these high $f$ PAR values is related to sensor failure. Both the very low $f$ PAR values for the Western Peatland and $f$ PAR values greater than 1 at the Mer Bleue were excluded in this study. Future work using MODIS $f$ PAR will use the de-bugged data from Boston University: ftp://primavera.bu.edu/pub/datasets/MODIS/.

\subsection{Growth limiting factors: VPD and Tmin}

VPD was calculated using Eqs. 5 and 6 with the data for both Mer Bleue and the Western Peatland. The VPD for the Mer Bleue was then plotted against $\varepsilon$. At the Mer Bleue the VPD was not a limiting factor on $\varepsilon$ (Fig. 3). This may be due to the high water tables found at each site. However, Tmin was a limiting factor on $\varepsilon$ at both sites. When Tmin was plotted against $\varepsilon$ it was clear that low temperatures affect $\varepsilon$ (Fig. 4). When the mean daily temperature drops below $-6^{\circ} \mathrm{C}$ at the Mer Bleue and $-10.6^{\circ} \mathrm{C}$ at the Western peatland it becomes too cold for the plants to function and $\varepsilon$ is reduced to zero because the plants are not converting light into GPP. The temperature threshold difference between the two sites was not examined in detail however the difference could be attributed to the type of vegetation. The dominance of sphagnum mosses at the Mer Bleue site may be the cause of the higher temperature threshold. The physiological structure 
Temperature vs Light Use Efficency

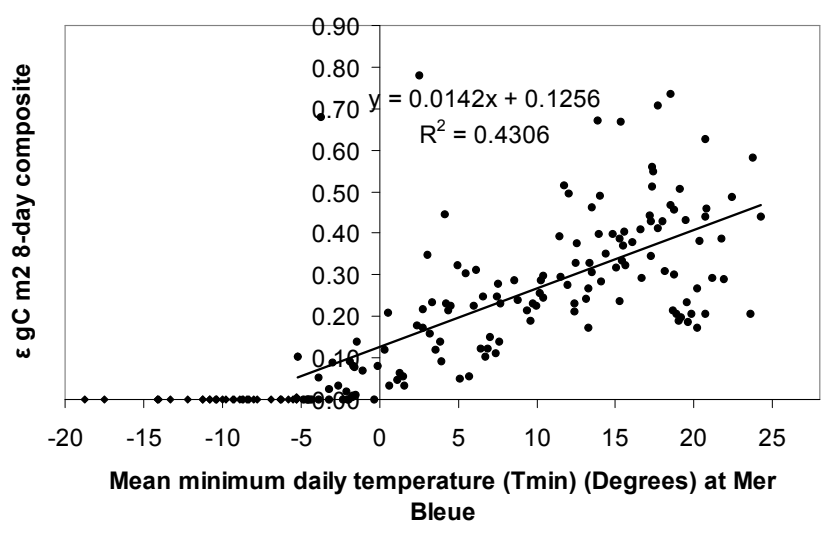

Fig. 4. The relationship between Mean minimum daily temperature (Tmin) and Epsilon at the Mer Bleue $(p=0.000)$.

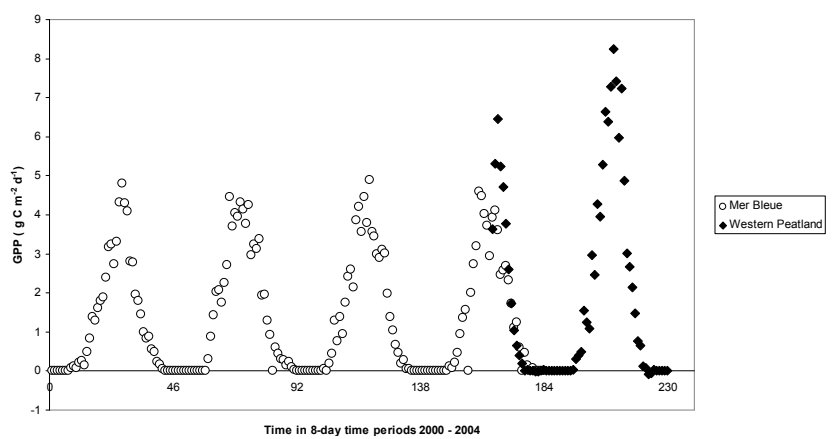

Fig. 5. Average daily GPP for an 8-day time period (46 and a bit 8-day time periods in a year) for the Mer Bleue bog, Ontario, (20002003) and for the Western Peatland, Alberta, (end 2003-2004).

of the mosses means that they cannot control their internal water content and cold temperatures will also exert more of an affect on these plants as they do not have well developed vascular systems (Busby et al., 1978; Bisbee, et al., 2001). The dominant vegetation at the Western Peatland is Picea mariana and Larix laricina. These trees are physiologically adapted to colder temperatures and the may explain why the temperature threshold is lower at this site (Loehle, 1998).

\subsection{Gross primary production}

GPP was calculated using Eq. (3) and NEE and ER data. The maximum daily 8-day average GPP at Mer Bleue for the four years reported was about $5 \mathrm{~g} \mathrm{C} \mathrm{m}^{-2} \mathrm{~d}^{-1}$ (Fig. 5), whereas the maximum for the Western Peatland was about $8.5 \mathrm{~g} \mathrm{C} \mathrm{m}^{-2} \mathrm{~d}^{-1}$ (Fig. 5). The difference between these values is statistically significant $(p=0.000)$. At both sites there was a seasonal pattern that followed trends in $\downarrow$ PAR and $f$ PAR. GPP is reduced to zero in winter because snow cover and low temperatures reduce photosynthesis to zero. Conse-

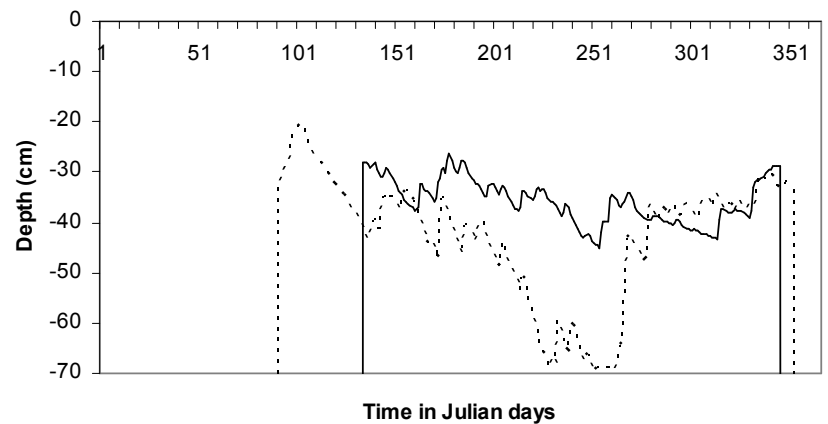

Fig. 6. Water table at Mer Bleue in 2000 (solid line) versus 2001 (dashed line).

quently measured NEE directly reflects ER. GPP starts to accumulate when the snow season ends which is usually at the end of March or early April for the Mer Bleue bog (Lafleur at al., 2003) and around the same time for the Western Peatland. The peak GPP at Mer Bleue varies between years, in 2001 and 2003 it was earlier in the season than in 2000 and 2002. The maximum 8-day average GPP values for all years varied from $4.5 \mathrm{~g} \mathrm{C} \mathrm{m}^{-2} \mathrm{~d}^{-1}$ to $5 \mathrm{~g} \mathrm{C} \mathrm{m}^{-2} \mathrm{~d}^{-1}$, with the highest occurring in 2002. This variation might be attributed to weather conditions e.g. 2000 was a much wetter year than 2001 (Bubier et al., 2003) this can be seen in Fig. 6. where the water table in 2000 is clearly nearer the surface than in 2001. However, the evidence suggests that the variation in GPP between the four years at the Mer Bleue is not statistically significant. ( $p=0.706)$ therefore uncertainty surrounding the effect of weather conditions on GPP during each year can be deemed in the case of these data to have little effect. The length of the growing season is similar for both sites but GPP was considerably higher at treed Western Peatland where the maximum 8-day average GPP value for 2004 was $8.25 \mathrm{~g} \mathrm{C} \mathrm{m}^{-2} \mathrm{~d}^{-1}$.

\subsection{Light use efficiency parameter $(\varepsilon)$}

As expected the light use efficiency parameter for both sites followed the seasonal patterns of $\downarrow$ PAR, $f$ PAR and GPP. The maximum $\varepsilon$ value for each of the four years at the Mer Bleue bog ranges from $0.71 \mathrm{~g} \mathrm{C} \mathrm{MJ}^{-1}$ in 2000 to $0.78 \mathrm{~g} \mathrm{C} \mathrm{MJ}^{-1}$ in 2003 (Fig. 7). The maximum value in 2002 was much lower at around $0.60 \mathrm{~g} \mathrm{C} \mathrm{MJ}^{-1}$. In order to determine the start, end and time of peak of the growing season for each year a curve was fitted through the data (Fig. 7):

$\varepsilon^{\prime}=a+b \times \cos (c \mathrm{t}+d)$

where $\varepsilon^{\prime}=$ estimated $\varepsilon$ parameter value, $\mathrm{t}=$ day of year and $a, b, c$, and $d$ are fitting parameters. The parameters were interpreted such that $a$ and $b$ reflect the magnitude of the peak $\varepsilon_{\max }$ value for each year. $c$ reflects the length of the growing season (the smaller $c$ is the longer the growing season) and $d$ 


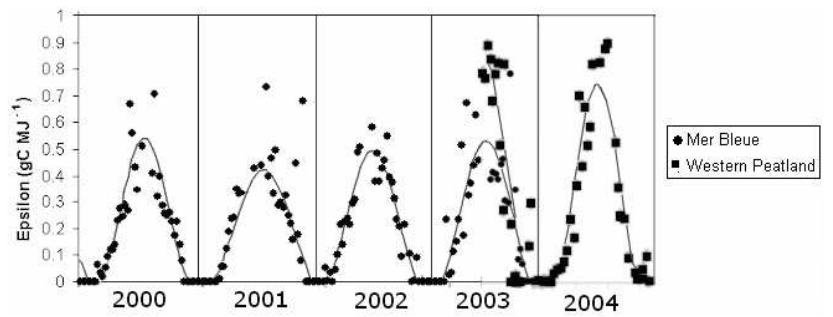

Fig. 7. Comparison of fitted line from Eq. (5) and the peak $\varepsilon$ for the Mer Bleue (2000 to 2003) and at Western Peatland (2003 to 2004).

reflects when the peak value occurs $(a, b, c$ and $d$ are unitless values) (Table 1).

The growing season begins and ends at Mer Bleue at similar times in every year except 2001 when it ends much later (Fig. 8). At the Western Peatland, it starts slightly later and ends much earlier than at Mer Bleue. The Mer Bleue bog $\varepsilon_{\max }$ is interesting, in 2000 and 2003, the pattern between both curves is almost the same especially around midsummer. In 2002, the pattern is very similar but the $\varepsilon_{\max }$ is lower. In 2001, a drier than normal year (Bubier et al., 2003), the $\varepsilon_{\max }$ is later and much lower (Fig. 8). Various weather patterns may explain the differing peaks and growing season lengths, for example 2001 was very dry (Bubier et al., 2003), in Fig. 8, the peak epsilon value on the curve is $\sim 0.41 \mathrm{~g} \mathrm{C} \mathrm{MJ}^{-1}$, about $0.1 \mathrm{~g} \mathrm{C} \mathrm{MJ}^{-1}$ lower than the other three years. This peak also occurs two to three weeks later than in the other years. However, these differences are not statistical significant ( $p=0.709$ ). The $\varepsilon_{\max }$ in 2004 , for the Western peatland occurs slightly earlier in the year and is $\sim 50 \%$ higher than at Mer Bleue. This pattern can also be found in the measured data where $\varepsilon_{\max }$ at Western Peatland is higher than that at Mer Bleue, $0.91 \mathrm{~g} \mathrm{C} \mathrm{MJ}^{-1}$ versus $0.78 \mathrm{~g} \mathrm{C} \mathrm{MJ}^{-1}$. The reason for this is due to the greater productivity of trees at the Western peatland site.

Early work with the $\varepsilon$ approach assumed a constant $\varepsilon$ but later studies have shown that there is variation between biomes and throughout the year (Turner et al., 2003; Ahl et al., 2004; Brogaard et al., 2005). Our results found that $\varepsilon$ varied throughout the year and followed a fairly predictable seasonal pattern. The average growing season at Mer Bleue is from May to September and at the Western Peatland is from May to October (Lafleur et al., 2003; Syed et al., 2006).

A number of factors can affect the photosynthetic efficiency of plants, influencing $\varepsilon$, such as in-situ environmental conditions: soil moisture, water table position (Lafleur et al., 2003), nutrient availability and weather conditions. There is some uncertainty around how individual species respond to different condition however in this study we are capturing the ecosystem response thus the responses of individual species are averaged out. $\varepsilon$ (believed to be constant, Monteith, 1972; Potter et al., 2003) can be attenuated by temperature and vapour pressure deficit (VPD) limitations (Run-

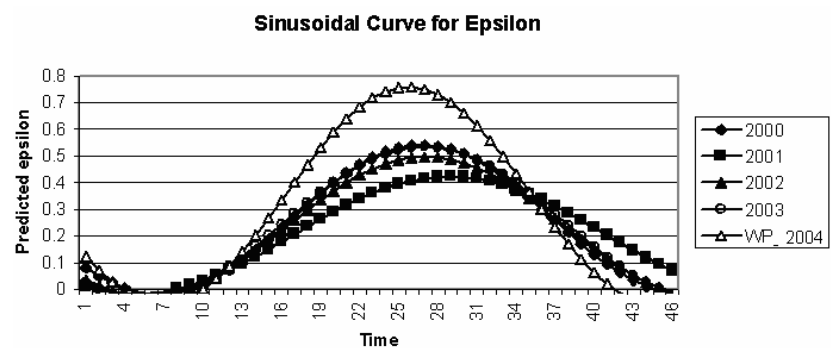

Fig. 8. Curves fitted to the data estimating the length of the growing season, the peak value $\left(\varepsilon_{\max }\right)$, and the peak occurrence. ( $\boldsymbol{\vee}=$ MB_2000, $\boldsymbol{\square}=$ MB_2001, $\boldsymbol{\Delta}=$ MB_2002. $\bigcirc=$ MB_2003).

Table 1. The parameter values (unitless) for the curves estimating growing season length, peak and peak occurrence ( $a$ and $b=$ the magnitude of the peak LUE value for each year, $c=$ the length of the growing season (the smaller $\mathrm{c}$ is the longer the growing season) and $d=$ when the peak value occurs).

\begin{tabular}{llllll}
\hline & \multicolumn{3}{c}{ Mer Bleue } & & $\begin{array}{l}\text { Western } \\
\text { Peatland }\end{array}$ \\
\hline Parameters & 2000 & 2001 & 2002 & 2003 & 2004 \\
\hline$a$ & 0.218 & 0.178 & 0.2 & 0.198 & 0.389 \\
$b$ & 0.235 & 0.195 & 0.215 & 0.219 & 0.447 \\
$c$ & 0.018 & 0.015 & 0.017 & 0.017 & 0.019 \\
$d$ & -3.733 & -3.374 & -3.736 & -3.539 & -4.164 \\
\hline
\end{tabular}

ning et al., 2000). An examination of the data used in this study indicated that, for both sites in Canada, low temperatures reduced $\varepsilon$ relative to $\varepsilon_{\max }$ but that VPD had no effect. At Mer Bleue, as the temperature approached -6 to $-7^{\circ} \mathrm{C}$ $\varepsilon$ is close to zero and beyond $-10^{\circ} \mathrm{C} \varepsilon$ is reduced to zero. Similarly at the Western Peatland in 2004 as the temperature nears $-9.5^{\circ} \mathrm{C} \varepsilon$ is close to zero and beyond $-10.5^{\circ} \mathrm{C} \varepsilon$ is reduced to zero. The $\varepsilon_{\max }$ occurs in mid summer and ranges from between $0.58 \mathrm{~g} \mathrm{C} \mathrm{MJ}^{-1}$ and $0.78 \mathrm{~g} \mathrm{C} \mathrm{MJ}^{-1}$ for the Mer Bleue bog for the years 2000 to 2003 and was $0.91 \mathrm{~g} \mathrm{C} \mathrm{MJ}^{-1}$ for the Western Peatland in 2004.

The average $\varepsilon$ for the snow free period (April to November) for the Mer Bleue bog over the four years was $0.27 \mathrm{~g} \mathrm{C} \mathrm{MJ}^{-1}$ and for the Western Peatland for 2004 was $0.39 \mathrm{~g} \mathrm{C} \mathrm{MJ}^{-1}$. The average growing season (May to September, Lafleur et al., 2003) $\varepsilon$ for the Mer Bleue bog ranged between $0.32 \mathrm{~g} \mathrm{CMJ}^{-1}$ in 2001 to $0.38 \mathrm{~g} \mathrm{C} \mathrm{MJ}^{-1}$ in 2003 and the growing season (May through October, Syed et al., 2006) $\varepsilon$ in 2004 for the Western Peatlands was $0.57 \mathrm{~g} \mathrm{CMJ}^{-1}$. These average growing season values are comparable to the growing season value for a forested wetland in northern Wisconsin of $0.37 \mathrm{~g} \mathrm{CMJ}^{-1}$ (Ahl et al., 2004). 


\section{Conclusions}

The LUE was derived for two Canadian peatland sites using satellite and flux tower data. The spatial and temporal variation of $\varepsilon_{\max }$ between the Western peatland site $\left(0.91 \mathrm{~g} \mathrm{C} \mathrm{MJ}^{-1}\right)$ and the Mer Bleue site $\left(0.78 \mathrm{~g} \mathrm{C} \mathrm{MJ}^{-1}\right)$ may be attributed to differences in the climate and vegetation at each site. There are some truncated records of LAI for the Mer Bleue however there is no LAI data for the Western Peatland therefore the use of satellite derived MODIS $f$ PAR, which can be substituted for LAI, is advantageous. Midsummer MODIS $f$ PAR performed as expected when compared to LAI derived $f$ PAR calculated using Beer's law and published data for the Mer Bleue. This method which combines satellite data with flux tower observations could lead to the characterisation of $\varepsilon$ and $\varepsilon_{\max }$ not only for other peatlands but also for different biomes.

Acknowledgements. We would like to extend thanks to Enterprise Ireland for supporting this work through the International Collaboration Travel Support grant and Shane Colgan of the Environmental Protection Agency (Ireland) for the Short Term Research Mission grant both of which enabled this research to be conducted at McGill University, Canada. We also wish to thank Lawrence B. Flanagan and the Fluxnet Canada Research Network for providing the Western Peatland data.

Edited by: A. Arneth

\section{References}

Ahl, D. E., Gower, S. T., Mackay, D. S., Burrows, S. N., Norman, J. M., and Diak, G. R.: Heterogeneity of light use efficiency in a northern Wisconsin forest: implications for modelling net primary production with remote sensing, Remote Sens. Environ., 93, 168-178., 2004.

Ahl, D. E., Gower, S. T., Mackay, D. S., Burrows, S. N., Norman, J. M., and Diak, G. R.: The effects of aggregated land cover data on estimating NPP in northern Wisconsin, Remote Sens. Environ., 97, 1-14, 2005.

Albritton, D. L. and Meira Filho, L. G.: Technical summary of the working group I to the third assessment report of the intergovernmental panel of climate change, Cambridge: Intergovernmental Panel of Climate Change, 21-83, 2001.

Arneth, A., Kurbatova, J., Kolle, O., Shistova, O. B., Lloyd, J., Vygodskaya, N. N., and Schulze, E.-D.: Comparative ecosystematmosphere exchange of energy and mass in a European Russian and a central Siberian bog II. Interseasonal and interannual variability of $\mathrm{CO}_{2}$ fluxes, Tellus, 54B, 514-530, 2002.

Aurela, M., Laurila, T., and Tuovinen, J.-P.: Annual $\mathrm{CO}_{2}$ balances of a subarctic fen in northern Europe: Importance of the wintertime efflux, J. Geophys. Res., 107(D21), 4607, doi:10.1029/2002JD002055, 2002.

Bisbee, K. E., Gower, S. T., Norman, J. M., and Nordheim, E. V.: Environmental controls on ground cover species composition and productivity in a boreal black spruce forest, Oecologia, 129, 261$270,2001$.
Brogaard, S., Runnstrom, M., and Seaquist, J. W.: Primary production of Inner Mongolia, China, between 1982 and 1999 estimated by a satellite data-driven light use efficiency model, Global Planet Change, 45, 313-332, 2005.

Bubier, J. L., Bhatia, G., Moore, T. R., Roulet, N. T., and Lafleur, P. M.: Spatial and temporal variability in growing season net ecosystem carbon dioxide exchange at a large peatland in Ontario, Canada, Ecosystems, 6, 353-367, 2003.

Busby, J. R., Bliss, L. C., and Hamilton, C. D.: Microclimate control of growth rates and habitats of the boreal forest mosses, Tomenthypnum nitens and Hylocomium splendens, Ecol. Monogr., 48, 95-110, 1978.

Coursolle, C., Margolis, H., Barr, A., et al.: Late-summer carbon fluxes from Canadian forests and peatlands along an east-west continental transect, Can. J. Forest Res., 36, 783-800, 2006.

Doraiswamy, P., Muratova, N., Sinclair, T., Sterm, A., and Akhmedov, B.: Evaluation of MODIS Data for assessment of regional spring wheat yield in Kazakhstan, Digest of IGARSS 1, 487-490, Piscataway, NJ: IEEE, 2002.

Fan, S.-M., Goulden, M. L., Munger, J. W., Daube, B. C., Bakwin, P. S., Wofsy, S. C., Amthor, J. S., Fitzjarrald, D. R., Moore, K. E., and Moore, T. R.: Environmental controls on the photosynthesis and respiration of a boreal lichen woodland: a growing season of whole-ecosystem exchange measurements by eddy correlation, Oecologia, 102, 443-452, 1995.

Fensholt, R., Sandholt, I., and Rasmussen, S.: Evaluation of MODIS LAI, fAPAR and the relation between fAPAR and NDVI in a semi-arid environment using in situ methods, Remote Sens. Environ., 91, 490-507, 2004.

Frolking, S., Roulet, N. T., Moore, T. R., Lafleur, P. M., Bubier, J. L., and Crill, P. M.: Modeling seasonal to annual carbon balance of Mer Bleue Bog, Ontario, Canada, Global Biogeochem. Cy., 16(3), 1030, doi:10.1029/2001GB001457, 2002.

Goetz, S. J. and Prince, S. D.: Variability in carbon exchange and light utilization among boreal forest stands: implications for remote sensing of net primary production, Can. J. Forest Res., 23, 243-251, 1998.

Goetz, S. J. and Prince, S. D.: Modelling terrestrial carbon exchange and storage: evidence and implications of functional convergence in light-use efficiency, Adv. Ecol. Res., 28, 57-92, 1999.

Goetz, S. J., Prince, S. D., Goward, S. N., Thawley, M. M., and Small, J.: Satellite remote sensing of primary production: an improved production efficiency modelling approach, Ecol. Model, 122, 239-255, 1999.

Gorham, E.: Northern Peatlands: role in the carbon cycle and probable responses to climatic warming, Ecol. Appl., 1, 182-192, 1991.

Gorham, E., Janssens, J. A., and Glaser, P. H.: Rates of peat accumulation during the postglacial period in 32 sites from Alaska to Newfoundland, with special emphasis on northern Minnesota, Can. J. Bot., 81, 429-438, 2003.

Gower, S. T., Kucharik, C. J., and Norman, J. M.: Direct and indirect estimation of leaf area index, $f$ APAR and net primary production of terrestrial ecosystems, Remote Sens. Environ., 70, 29-51, 1999.

Heinsch, F. A., Reeves, M., Votava, P., Kang, S., Milesi, C., Zhoa, M., Glassy, J., Jolly, W. M., Loehman, R., Bowker, C. F., Kimball, J. S., Nemani, R. R., and Running, S. W.: User's Guide 
GPP and NPP (MOD17A2/A3) products NASA MODIS land algorithm, USGS-NASA - Technical Report, 2003.

Hodges, J.: MODIS MOD12 Land cover and land cover dynamics products user guide, http://geography.bu.edu/landcover/ userguidelc/index.html, 2002.

Hunt Jr., E. R.: Relationship between woody biomass and PAR conversion efficiency for estimating net primary production from NDVI, Int. J. Remote Sens., 15, 1725-1730, 1994.

Justice, C. O., Vermote, E., Townshend, J. R. G., Defries, R., Roy, D. P., Hall, D. K., Salomonson, V., V., Privette, J. L., Riggs, G., Strahler, A., Lucht, W., Myneni, R. B., Knyazikhin, Y., Running, S. W., Nemani, R. R., Wan, Z., Huete, A. R., Van Leeuwen, W., Wolfe, R. E., Giglio, L., Muller, J.-P., Lewis, P., and Barnsley, M. J.: The moderate resolution imaging spectroradiometer (MODIS): land remote sensing for global change research, IEEE T. Geosci. Remote, 36, 1228-1235, 1998.

Kimball, J. S., Keyser, A. R., Running, S. W., and Saatchi, S. S.: Regional assessment of boreal forest productivity using an ecological process model and remote sensing parameter maps, Tree Physiol., 20, 761-775, 2000.

Lafleur, P. M., Roulet, N. T., and Admiral, S. W.: Annual cycle of $\mathrm{CO}_{2}$ exchange at a bog peatland, J. Geophys. Res., 106, 30713081, 2001.

Lafleur, P. M., Roulet, N. T., Bubier, J. L., Frolking, S., and Moore, T. R.: Interannual variability in the peatland-atmosphere carbon dioxide exchange at an ombrotrophic bog, Glob. Biogeochem. Cy., 17(2), 1036, doi:10.1029/2002GB001983, 2003.

Lafleur, P. M., Moore, T. R. Roulet, N. T., and Frolking, S.: Ecosystem respiration in a cool temperate bog depends on peat temperature but not water table, Ecosystems, 8, 619-629, 2005.

Law, B. E., Waring, R. H., Anthoni, P. M., and Aber, D.: Measurements of gross and net ecosystem productivity and water vapour exchange of a Pinus ponderosa ecosystem, and an evaluation of two generalized models, Glob. Change Biol., 6, 155-168, doi:10.1046/j.1365-2486.2000.00291.x, 2000.

Lobell, D. B., Hicke, J. A., Asner, G. P., Field, C. B., Tucker, C. J., and Los, S.O.: Satellite estimates of productivity and light use efficiency in United States agriculture, 1982-1998, Glob. Change Biol., 8, 722-735, doi:10.1046/j.1365-2486.2002.00503.x, 2002.

Loehle, C.: Height growth rate tradeoffs determine northeren and southern range limits for tree, J. Biogeogr., 25, 735-742, 1998.

Lopes, P., Lorenço. P., Carvalhais, N., and Seixas, J.: MODIS land cover product validation in the Iberian peninsula, Geosci. Remote Sens. Symp., (IGARSS 03), 3, 1733-1735, 2003.

Lotsch, A., Tian, Y., Friedl, M. A., and Myneni, R. B.: Land cover mapping in support of LAI and $f$ PAR retrievals from EOSMODIS and MISR: classification methods and sensitivities to errors, Int. J. Remote Sens., 24, 1997-2016, 2003.

Malmer, N. and Wallén, B.: Input rates, decay losses and accumulation rates of carbon in bogs during the last millennium: internal processes and environmental changes, Holocene, 14, 111-118, 2004.

Monteith, J. L.: Solar radiation and productivity in tropical ecosystems, J Appl. Ecol., 9, 747-766, 1972.

Moore, T. R., Roulet, N. T., and Waddington, J. M.: Uncertainties in predicting the effect of climatic change on the carbon cycling of Canadian peatlands, Clim. Change, 40, 229245, doi:10.1023/A:1005408719297, 1998.

Moore, T. R., Bubier, J. L., Frolking, S. E., Lafleur, P. M., and
Roulet, N. T.: Plant biomass and production and $\mathrm{CO}_{2}$ exchange in an ombrotrophic bog, J. Ecol., 90, 25-36, 2002.

Myneni, R. B., Hoffman, S., Knyazikhin, Y., Privette, J. L., Glassy, J., Tian, Y., Wang, Y., Song, X., Zhang, Y., Smith, G. R., Lotsch, A., Friedl, M., Morisette, J. T., Votava, P., Nemani, R. R., and Running S. W.: Global products of vegetation leaf area and fraction absorbed PAR from year one of MODIS data, Remote Sens. Environ., 83, 214-231, 2002.

Myneni, R., Knyazikhin, Y., Glassy, J., Votava, P., and Shabanov, N.: User's guide $f$ PAR, LAI (ESDT: MOD15A2) 8-day composite NASA MODIS land algorithm, Terra MODIS land team, http://cybele.bu.edu/modismisr/products/modis/userguide. pdf, 2003.

Potter, C. S., Randerson, J. T., Field, C. B., Matson, P. A., Vitousel, P. M., Mooney, H. A., and Klooster, S. A.: Terrestrial ecosystem production - a process model based on global satellite and surface data, Glob. Biogeochem. Cy., 7, 811-841, 1993.

Potter, C., Klooster, S., Genovese, V., and Myneni, R.: Satellite data help predict terrestrial carbon sinks, EOS Transactions AGU, 84, 502-508, 2003

Roulet, N. T., Lafleur, P. M., Richard, P. J. H., Moore, T. R., Humphreys, E. R., and Bubier, J. L.: Contemporary carbon balance and late Holocene carbon accumulation in a northern peatland, Glob. Change Biol., 13, 397-411, doi:10.1111/j.13652486.2006.01292.x, 2007.

Ruimy, A., Saugier, B., and Dedieu, G.: Methodology for the estimation of terrestrial net primary production from remotely sensed data, J. Geophys. Res., 99, 5263-5283, 1994.

Running, S. W., Baldocchi, D. D., Turner, D. P., Gower, S. T., Bakwin, P. S., and Hibbard, K. A.: A global terrestrial monitoring network integrating tower fluxes, flask sampling, ecosystem modeling and EOS satellite data, Remote Sens. Environ., 70, 108-127, 1999.

Running, S. W., Thornton, P. E., Nemani, R., and Glassy, J. M.: Global terrestrial gross and net primary productivity from the earth observing system, in: Methods in Ecosystem Science (4457), edited by: Sala, O. E., Jackson, R. B., Mooney, H. A., and Howarth, R. W., New York: Springer, 2000.

Running, S. W., Nemani, R. R., Heinsch, F. A., Zhao, M., Reeves, M., and Hashimoto, H.: A continuous satellite-derived measure of global terrestrial primary production, Bioscience, 54, 547560, 2004.

Salomonson, V. V., Barnes, W., Xiong, J., Kempler, S., and Masouka, E.: An overview of the Earth observing system MODIS instrument and associated data systems performance, Proceedings of the International Geoscience and Remote Sensing Symposium, (IGARSS 02) 2, 1174-1176, 2002.

Savtchenko, A., Ouzounov, D., Gopalan, A., Yuan, D., Nickless, D., and Ostrenga, D.: MODIS data from Terra and Aqua satellites, IEEE T. Geosci. Remote., 5, 3028-3030, 2003.

Seaquist, J. W., Olsson, L., and Ardo, J.: A remote sensing-based primary production model for grassland biomes, Ecol. Model, 169, 131-155, 2003.

Sims, D. A., Rahman, A. F., Cordova, V. D., Baldocchi, D. D., Flanagan, L. B., Goldstein, A. H., Hillinger, D. Y., Misson, L., Monson, R. K., Schmid, H. P., Wofsy, S. C., and Xu, L.: Midday values of gross $\mathrm{CO}_{2}$ flux and light use efficiency during satellite overpasses can be used to directly estimate eight-day mean flux, Ag. Forest Meteorol., 131, 1-12, 2005. 
Smith, C. R. and Lafleur, P. M.: Wintertime net ecosystem exchange of $\mathrm{CO}_{2}$ from the Mer Bleue Bog peatland: results from a field study. Proceedings of the $60^{\text {th }}$ Eastern Snow Conference, Sherbrooke, Québec, Canada, 2003.

Snyder, R. L. and Paw U. K. T.: Measuring vapour pressure deficit in the field. University of California, http://biomet.ucdavis.edu/ biomet/VPD/vpd.htm, 2006.

Sonnentag, O., Talbot, J., Chen, J. M., and Roulet, N. T.: Using direct and indirect measurements of leaf area index to characterize the shrub canopy in an ombrotrophic peatland, Ag. Forest Meteorol., 144(3-4,) 200-212, 2007.

Syed, K. H., Flanagan, L. B., Carlson, P. J., Glenn, A. J., and Van Gaalen, K. E.: Environmental control of net ecosystem $\mathrm{CO}_{2}$ exchange and carbon balance in a treed, moderately rich fen in northern Alberta, Ag. Forest Meteorol., 140, 97-114, 2006.

Turner, D. P., Gower, S. T., Cohen, W. B., Gregory, M., and Maiersperger, T. K.: Effects of spatial variability in light use efficiency on satellite based NPP monitoring, Remote Sens. Environ., 80, 397-405, 2002.

Turner, D. P., Urbanski, S., Bremer, D., Wofsy, S. C., Meyers, T., Gower, S. T., and Gregory, M.: A cross-biome comparison of daily light use efficiency for gross primary production, Glob. Change Biol., 9, 383-395, doi:10.1046/j.13652486.2003.00573.x, 2003.
Turner, D. P., Ritts, W. D., Cohen, W. B., Maiersperger, T. K., Gower, S. T., Kirschbaum, A. A., Running, S. W., Zhoa, M., Wofsy, S. C., Dunn, A. L., Law, B. E., Campbell, J. L., Oechel, W. C., Kwon, H. J., Meyers, T. P., Small, E. E., Kurc, S. A., and Gamon, J. A.: Site-level evaluation of satellitebased global terrestrial gross primary production and net primary production monitoring, Glob. Change Biol, 11, 666-684, doi:10.1111/j.1365-2486.2005.00936.x, 2005.

Vitt, D. H., Halsey, L. A., Bauer, I. E., and Campbell, C.: Spatial and temporal trends in carbon storage of peatlands of continental western Canada through the Holocene, Can. J. Earth Sci., 37, 683-693, 2000.

Wan, Z., Zhang, Y., Zhang, Q., and Li, Z.-L.: Quality assessment and validation of the MODIS global land surface temperature, Int. J. Remote Sens., 25, 261-274, 2004.

Wang, Y., Tian, Y., Zhang, Y, El-Saleous, N., Knyazikin, Y., Vermote, E., and Myneni, R. B.: Investigation of product accuracy as a function of input and model uncertainties Case study with SeaWiFS and MODIS LAI/ $f$ PAR algorithm, Remote Sens. Environ., 78, 299-313, 2001.

Yang, W., Huang, D., Tan, B., Stroeve, J. C., Shabanov, N. V., Knyazikhin, Y., Nemani, R. R., and Myneni, R. B.: Analysis of leaf area index and fraction of PAR absorbed by vegetation products from the Terra MODIS sensor: 2000-2005, IEEE T. Geosci. Remote., 44(7), 7, doi:10.1109/TGRS.2006.871214, 2006. 